\title{
Screening of celiac disease in children and adolescents with type 1 diabetes mellitus
}

\author{
Hasret Ayyıldız Civan', Esra Papatya Çakır²
}

'Department of Gastroenterology, Hepatology and Nutrition, Bakırköy Dr. Sadi Konuk Training and Research Hospital, Istanbul, Turkey

${ }^{2}$ Department of Pediatric Endocrinology, Bakırköy Dr. Sadi Konuk Training and Research Hospital, Istanbul, Turkey

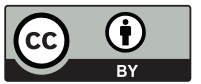

This work is licensed under a Creative Commons Attribution 4.0 International License

\section{Received: 2020-03-22}

Accepted: 2020-03-23

UDC: 618.1

\section{J Clin Med Kaz 2020; 2(56):21-26}

Corresponding Author: Hasret Ayyldız Civan, Bakırköy Dr. Sadi Konuk Eğitim ve Araştırma Hastanesi, İstanbul, Turkey. Tel.: +905057479765

E-mail: hasretayyildiz@yahoo.com

\section{Abstract}

Background and aim: Celiac disease is the most frequent autoimmune disease in Type 1 diabetes mellitus. We aimed to determine the celiac disease prevalence in patients with type 1 diabetes mellitus, additionally to evaluate the clinical, serological and molecular characteristics of type 1 diabetes mellitus and celiac disease which have a common genetic predisposition.

Material and methods: A total number of 76 type 1 diabetes mellitus patients aged between 1-18 years, were evaluated retrospectively. Serologic screening for celiac disease was performed via anti-tissue transglutaminase and anti-endomysial antibodies. Presence of human leukocyte antigens (HLA) (DQ2 and DQ8) documented as well. Patients with positive tissue transglutaminase and endomysial antibodies underwent endoscopic biopsy. Histopathological analysis were performed according to the modified Marsh classification. Patients' demographic characteristics, anthropometric measurements, physical examination, laboratory findings, age at type 1 diabetes mellitus and celiac disease onset, and celiac disease prevalence were evaluated. In addition all findings were compared between type 1 diabetes mellitus patients and newly diagnosed celiac disease patients.

Results: Serum tissue transglutaminase was positive in $14,5 \%(n=11)$ of all patients and serum endomysial antibodies was positive in $13,2 \%(n=10)$. The overall prevalence of celiac disease in type 1 diabetes mellitus was confirmed as $10.5 \%(n=8)$ by histopathological examination in present study. Of the celiac disease patients $37.5 \%$ were asymptomatic. In addition, 6 were anti-tissue transglutaminase and 7 were endomysial antibodies positive. Moreover, $60.3 \%$ $(n=41)$ were HLADQ2 and $58.8 \%(n=40)$ were HLA-DQ8 positive. Selective IgA deficiency was described in 3 cases. In one of them HLA-DQ2/HLA-DQ8 was found positive and celiac disease diagnosis was confirmed by biopsy. HLADQ8 ratio was found significantly higher in patients with celiac disease than the type 1 diabetes mellitus patients. In addition, HLA-DQ2/DQ8 positivity was observed in $62.5 \%(n=5)$ of celiac disease patients.

Conclusion: Our findings have demonstrated the increasing prevalence of celiac disease in children with type 1 diabetes mellitus. Particularly the higher risk of asymptomatic celiac disease in type 1 diabetes mellitus patients, revealed the diagnostic value of serological screening. Furthermore, increased HLA-DQ2 and HLA-DQ8 positivity, which are more prominent in case of selective IgA deficiency, clearly demonstrates the requirement of routine total IgA and HLA analysis in serological screening.

Key words: type 1 diabetes mellitus, celiac disease, serological screening, human leukocyte antigens

\section{1 ТИПТІ ҚАНТ ДИАБЕТІ БАР БАЛАЛАР МЕН ЖАСӨСПІРІМДЕРДЕ ЦЕЛИАКИЯ АУРУЫН АНЫҚТАУ}

\author{
Х.А. Циван ${ }^{1}$, Э.П. Чакир ${ }^{2}$ \\ ${ }^{1}$ Гастроэнтерология, гепатология және тамақтану бөлімі, Доктор Сади Конук атындағы Бакыркөй ғылыми клиникасы, Ысмтамбұл, Түркия \\ ${ }^{2}$ Балалар эндокринологиясы бөлімі, Доктор Сади Конук атындағы Бакыркөй ғылыми клиникасы, Ыстамбұл, Түркия
}

Мақсаты: целиакия ауруы - 1 типті қант диабетіндегі ең көп таралған аутоиммундық ауру. Біздің зерттеуіміздің мақсаты 1 типті қант диабеті бар науқастарда целиакия ауруының таралуын анықтау, сонымен қатар жалпы генетикалық бейімділігі бар 1 типті қант диабеті мен целиакия ауруының клиникалық, серологиялық және молекулалық сипаттамаларын бағалау болды. 
Материалдар мен әдістер: Зерттеуге 1 жастан 18 жасқа дейінгі 1 типті қант диабетімен ауыратын 76 науқас енгізілді. Целиакия ауруына серологиялық скрининг трансглутаминазға қарсы антиденелер мен эндомизияға қарсы антиденелерді қолдана отырып жүргізілді. Адамның лейкоциттік антигендерінің (HLA) (DQ2 және DQ8) болуы да зертханалық зерттеулермен расталады. Эндоскопиялық биопсия трансглутаминазға қарсы антиденелер мен эндомизияға қарсы антиденелер үшін оң нәтижелері бар пациенттерде жасалды. Гистопатологиялық талдау Марштың модификацияланған жіктелуіне сәйкес жүргізілді. Демографиялық сипаттама, антропометриялық көрсеткіштер, фризикалық тексеру, зертханалық мәліметтер, 1 типті қант диабеті және целиакия ауруының басталу кезіндегі жас, сондай-ақ целиакия ауруының таралуы бағаланды. Сонымен қатар, барлық нәтижелер 1 типті қант диабеті бар науқастар мен жаңадан диагноз қойылған целиакия ауруы бар емделушілер арасында салыстырылды.

Нәтижелер: Трансглутаминазға қарсы антиденелерге арналған қан сарысуының нәтижесі барлық пациенттердің 14,5\% -ында (n = 11) оң, ал қан сарысуының эндомизияға антиденелер үшін тесті 13,2\% ( $n=10)$ оң болды. Осы зерттеуде 1 типті қант диабетіндегі целиакия ауруының жалпы таралуы гистопатологиялық зерттеу арқылы 10,5\% ( $\mathrm{n}=8$ ) ретінде расталды. Целиакия ауруы бар пациенттердің 37,5\% -ы симптомсыз болды. Сонымен қатар, 6 науқаста трансглутаминазға қарсы антиденелер, ал 7 емделушіде эндомизияға қарсы антиденелер бар. Сонымен қатар, 60,3\% (n = 41) HLADQ2 және 58,8\% (n = 40) HLA-DQ8-оң болды. 3 жағдайда оқшауланған IgA типіндегі жетіспеушілік сипатталды. Олардың біреуінде HLA-DQ2 / HLA-DQ8 оң болды, ал целиакия ауруы диагнозы биопсиямен расталды. HLA-DQ8 коэффициенті целиакия ауруы бар науқастарда 1 типті қант диабетімен ауыратындарға қарағанда едәуір жоғары болды. Coнымен қатар, HLA-DQ2 / DQ8-позитивтілігі целиакия ауруы бар пациенттердің 62,5\% -ында $(n=5)$ байқалды.

Қорытынды: Біздің нәтижелеріміз 1 типті қант диабетімен ауыратын балаларда целиакия ауруының кең таралғандығын көрсетті. Атап айтқанда, 1 типті қант диабеті бар пациенттерде симптомсыз целиакия ауруының жоғары қаупі серологиялық скринингтің диагностикалық маңыздылығын көрсетті. Сонымен қатар, оқшауланған IgA типті жетіспеушілік жағдайында айқын болатын HLA-DQ2 және HLA-DQ8 позитивтілігінің жоғарылауы серологиялық скринингте IgA және HLA жиынтықтарын стандартты талдау қажеттілігін айқын көрсетеді.

Негізгі сөздер: 1 типті қант диабеті, целиакия ауруы, серологиялық скрининг, адамның лейкоциттік антигендері

\section{ВЫЯВЛЕНИЕ ЦЕЛИАКИИ У ДЕТЕЙ И ПОДРОСТКОВ С САХАРНЫМ ДИАБЕТОМ 1 ТИПА}

\section{Х.А. Циван ${ }^{1}$ Э.П. Чакир ${ }^{2}$}

'Отделение гастроэнтерологии, гепатологии и питания, Научно-исследовательская клиника Бакыркёй имени доктора Сади Конук, Стамбул, Турция

${ }^{2}$ Отделение педиатрической эндокринологии, Научно-исследовательская клиника Бакыркёй имени доктора Сади Конук, Стамбул, Турция

\section{PEЗЮME}

Цель: Целиакия является наиболее частым аутоиммунным заболеванием при сахарном диабете 1 типа. Целью нашего исследования стало определение распространенности целиакии у пациентов с сахарным диабетом 1 типа, а также оценка клинических, серологических и молекулярных характеристик сахарного диабета 1 типа и целиакии, которые имеют общую генетическую предрасположенность.

Материалы и методы: Всего 76 больных сахарным диабетом 1 типа в возрасте от 1 до 18 лет были включены в исследование. Серологический скрининг на целиакию проведен с помощью антител против трансглутаминазы и антител к эндомизию. Наличие человеческих лейкоцитарных антигенов (HLA) (DQ2 и DQ8) также подтверждено результатами лабораторных исследований. Пациентам с положительными результатами на антитела против трансглутаминазы и антитела к эндомизию проведена эндоскопическая биопсия. Гистопатологический анализ проведен по модифицированной классификации Марша. Оценены демографические характеристики, антропометрические показатели, физикальное обследование, лабораторные данные, возраст при появлении сахарного диабета 1 типа и целиакии, а также распространенность целиакии. Кроме того, все результаты были сопоставлены между больными сахарным диабетом 1 типа и пациентами с впервые диагностированной целиакией.

Результаты: Анализ сыворотки крови на антитела против трансглутаминазы был положительный у 14,5\% (n=11) всех пациентов, а анализ сыворотки крови на антитела к эндомизию был положительным у 13,2\% ( $\mathrm{n}=10)$. В настоящей работе общая распространенность целиакии при сахарном диабете 1 типа была подтверждена гистопатологическим исследованием как 10,5\% (n=8). 37,5\% пациентов с целиакией были бессимптомными. Кроме того, положительный результат был у 6 пациентов на антитела против трансглутаминазы и у 7 пациентов на антитела к эндомизию. Более того, 60,3\% (n=41) были HLADQ2 и 58,8\% (n=40) HLA-DQ8-положительными. B 3 случаях описана изолированная недостаточность IgA-типа. В одном из них HLA-DQ2/HLA-DQ8 оказался положительным, а диагноз целиакии был подтвержден биопсией. Отношение HLA-DQ8 было значительно выше у пациентов с целиакией, чем у пациентов с сахарным диабетом 1 типа. Кроме того, HLA-DQ2/DQ8-позитивность наблюдалась у 62,5\% (n=5) пациентов с целиакией.

Заключение: Наши результаты показали растущую распространенность целиакии у детей с сахарным диабетом 1 типа. В частности, более высокий риск возникновения бессимптомной целиакии у больных сахарным диабетом 1 типа выявил диагностическую ценность серологического скрининга. Кроме того, повышенная позитивность HLA-DQ2 и HLA-DQ8, которая более выражена в случае изолированной недостаточности IgA-типа, ясно демонстрирует необходимость проведения стандартного анализа общего IgA и НLA при серологическом скрининге.

ключевые слова: сахарный диабет 1 типа, целиакия, серологический скрининг, человеческий лейкоцитарный антиген

\section{Introduction}

Type 1 diabetes mellitus (T1DM) is an immune mediated disease characterized by insulin deficiency or insufficiency as a result of the destruction of insulin-producing beta cells in the islets of langerhans. Childhood T1DM has increased rapidly in recent years and accounting for the approximately $2-3 \%$ of the general population [1]. T1DM was significantly associated with autoimmune diseases such as thyroid disease, celiac disease (CD) and Addison's disease [2]. $\mathrm{CD}$ is the most frequent autoimmune disorder coexisting with T1DM [3].

$\mathrm{CD}$ is a chronic immune-mediated disease characterized by inflammation and villous atrophy in the small intestine. CDpatients suffer from lifelong intolerance to the gluten contained in cereals particularly in wheat [4]. The CD prevalence in children and adolescents with T1DM varies between 1.6 and $16.4 \%$ in worldwide $[5,6]$.
Whether the initial diagnosis is T1DM or CD; both diseases have been numerously documented to exhibit strong comorbidity with each other [7]. Supportively, both diseases were significantly associated with the 'major histocompatibility complex class II antigen DQ2' encoded by common alleles [4]. Along with the accompanying pathology in T1DM, the lack of symptoms that indicate gluten-sensitive enteropathy in approximately half of $\mathrm{CD}$ patients further complicates clinical management $[8,9]$.

Therefore, in order to prevent malabsorption in asymptomatic CD-patients, all T1DM patients should be screened for early diagnosis of $\mathrm{CD}$. Although $\mathrm{CD}$-associated antibodies such as tissue transglutaminase-IgA (TGA), antiendomysialIgA (EMA) manifest high sensitivity in serologic screening, duodenal biopsy is the gold standard method especially in patients with negative serology $[1,10]$. Thus, we aimed to 
determine the CD prevalence in T1DM-patients, additionally to compare the clinical, serological and molecular characteristics of patients with T1DM and CD.

\section{Material and methods}

This study was performed with the Institutional Review Board protocol approval date 18/02/2019 and number 201929 in Istanbul Training and Research Hospital, Department of Gastroenterology, Hepatology and Nutrition, 01 January 2017 30 June 2018. A total number of 76 T1DM-patients aged between 1-18 years, were evaluated retrospectively. During application, height and weight percentiles of cases, as well as the body mass index (BMI) for patients over two years of age were determined.

Serologic screening for $\mathrm{CH}$ was performed using anti tissue transglutaminase antibodies (tTGAb) via enzyme-linked immunosorbent assay (ELISA). All patients also screened for anti-endomysial antibodies by the immunofluorescence method using human umbilical cord and fluorescein isothiocyanate conjugated anti human-IgA (INOVA, San Diego, Calif., USA). In case of serum IgA deficiency, total serum IgA levels were measured by nephelometry. Presence of HLA antigens (DQ2 and DQ8) determined via polymerase chain reaction (PCR) technique through genomic DNA isolated from the all patients' peripheral blood. Patients with positive tTGA and EmA underwent endoscopic biopsy from distal duodenum. Histopathological analysis were performed according to the modified Marsh classification [11]. All CD-confirmed patients were referred for a gluten-free diet and followed.

In addition, cell blood count analysis was performed on patients' venous blood samples. Haematological parameters were analysed using a haematology analyser (Cell-Dyne 3700, Abbott, Abbott Park, IL, USA). Biochemical analysis performed from serum samples by electro-chemiluminescence immunoassay on Beckman Coulter Unicel DXI 800 analyzer. Serum glycosylated hemoglobin (HbA1c) level $<7 \%$ determined as well metabolic control, between $7-9 \%$ as moderate metabolic control and $9 \%$ as poor metabolic control.

Patients' demographic characteristics, age at T1DM and $\mathrm{CH}$ onset, anthropometric measurements, physical examination, imaging and laboratory findings, were evaluated. In addition all findings were compared between T1DM-patients and newly diagnosed $\mathrm{CH}$-patients.

\section{Statistical analysis}

All the data were analysed with SPSS (Statistical Package for the Social Sciences) software for Windows (v21.0; IBM, Armonk, NY, USA). Individual and aggregate data were summarized using descriptive statistics including mean, standard deviations, medians (min-max), frequency distributions and percentages. Normality of data distribution was verified by Kolmogorov-Smirnov test. Comparison of the variables with normal distribution was made with Student t-test. The variables which were not normally distributed, the Mann Whitney and Kruskal Wallis tests were conducted to compare between groups. Evaluation of categorical variables was performed by Chi-Square test. P-Values of $<0.05$ were considered statistically significant.

\section{Results}

The 76 T1DM-patients included in this study were 45 $(59,2 \%)$ female, $31(40,8 \%)$ male, and the mean age of symptom onset was $139,16 \pm 46,99$ months (Ranged=40-120) in our sample group. Additionally, the mean age of total participants

was 95,67 $\pm 52,85$ months (Ranged: $0-215$ ) at the time of DM diagnosis. Six of the cases $(7.9 \%)$ were screened due to the CD history in family members, and one of these patients was diagnosed with $\mathrm{CD}$. The overall prevalence of CD in T1DM was confirmed as $10.5 \%(n=8)$ by histopathological examination in present study. The mean age of CD-patients was $109,20 \pm 56,10$ months (Ranged: 78-188) at the time of CD diagnosis (Table 1). The most common symptom reported in our patients was abdominal pain with a ratio of $32,9 \%(n=25)$ followed by constipation $(25.0 \%)$, and diarrhea $(11,8 \%)$ respectively. The $46.1 \%(n=35)$ of the all patients and $37.5 \%(n=3)$ of the CD patients were asymptomatic (Table 2).

Table 1

\begin{tabular}{|c|c|c|c|}
\hline & n (\%) & $\begin{array}{l}\text { Age (Months) } \\
(\text { Mean } \pm \text { SD) }\end{array}$ & P-value \\
\hline Male & $31(\% 40,8)$ & $142,90 \pm 50,40$ & \multirow[t]{2}{*}{0,485} \\
\hline Female & $45(\% 59,2)$ & $136,58 \pm 44,88$ & \\
\hline $\begin{array}{l}\text { Mean Age at Appli- } \\
\text { cation }\end{array}$ & $76(\% 100)$ & $139,16 \pm 46,99$ & \multirow[t]{3}{*}{-} \\
\hline $\begin{array}{l}\text { Mean Age at DM } \\
\text { Diagnosis }\end{array}$ & $76(\% 100)$ & $95,67 \pm 52,85$ & \\
\hline $\begin{array}{l}\text { Mean Age at CD Diag- } \\
\text { nosis }\end{array}$ & $8(\% 10,5)$ & $109,20 \pm 56,10$ & \\
\hline
\end{tabular}

$\mathrm{SD}=$ Standard Deviation

$*=p<0.05$ statistically significant.

\section{Table 2 Distribution of symptoms during application.}

\begin{tabular}{|l|l|l|}
\hline Symptoms & $\mathrm{n}$ & $\%$ \\
\hline Abdominal pain & 25 & $\% 32,9$ \\
Constipation & 9 & $\% 25,0$ \\
Diarrhea & 19 & $\% 11,8$ \\
Puffiness & 9 & $\% 11,8$ \\
Asymptomatic & 35 & $\% 46,1$ \\
\hline
\end{tabular}

According to the evaluation of anthropometric measurements obtained from all cases; mean height was $146,20 \pm 20,47 \mathrm{~cm}$, mean weight was $44,09 \pm 18,39 \mathrm{~kg}$, and mean BMI was $19,08 \pm 4,75$ (Ranged=12,0-38,0). In addition, laboratory outcomes are represented in Table 3 . There were no statistically significant differences found between the CD and T1DM groups according to the age, BMI and laboratory findings $(p>0,05)$ (Table 3$)$. Additionally, vitamin D deficiency was detected in $88,2 \%(n=67)$ of patients, folic acid deficiency in $1.3 \%(n=1)$ and vitamin B12 deficiency in 9.2\% $(n=7)$. Iron-deficiency anemia detected in 1 patient and selective IgA deficiency was detected in $3(3,9 \%)$ patients. Only $2.7 \%$ of patients $(n=2)$ had normal levels of glycosylated hemoglobin; well-controlled HbA1c was 10,5\%, moderate controlled HbA1c was $40,8 \%$ and poorly controlled HbA1c was $48,7 \%$.

In addition, anti-tTGA was positive in $14,5 \%(\mathrm{n}=11)$, antitransglutaminaz IgG (anti-tTGG) in 17,1\% $(\mathrm{n}=13)$, anti-EMA in $13,2 \%(\mathrm{n}=10)$ and antiendomisyum IgG (anti-EMG) in 7,9\% $(n=6)$ of all patients. Of the CD patients, 6 were anti-tTGA and 7 were EMA positive.

The distribution of patients according to the tissue groups analysis $(n=68) ; 60.3 \%(n=41)$ were HLADQ2 and $58.8 \%$ $(n=40)$ were HLA-DQ8 positive. Moreover, rates of HLA-DQ8, anti-tTGA, anti-tTGG, anti-EMA and anti-EMG were found significantly higher in patients with CD than the T1DM patients (Table 4). 


\begin{tabular}{|l|l|l|l|}
\hline & $\begin{array}{l}\text { DM Group } \\
\text { (Mean } \pm \text { SD) }\end{array}$ & $\begin{array}{l}\text { CD Group } \\
\text { (Mean } \pm \text { SD) }\end{array}$ & P-value \\
\hline Age & $140,56 \pm 47,04$ & $127,25 \pm 47,95$ & 0,515 \\
\hline BMI & $19,29 \pm 4,80$ & $16,83 \pm 3,76$ & 0,146 \\
\hline HbA1c (\%) & $9,10 \pm 2,06$ & $9,61 \pm 2,33$ & 0,542 \\
\hline Hemoglobin (g/dL) & $13,45 \pm 1,17$ & $12,88 \pm 1,04$ & 0,115 \\
\hline MCV (fL) & $80,74 \pm 7,07$ & $82,32 \pm 6,57$ & 0,747 \\
\hline Iron (ug/dL) & $81,01 \pm 33,51$ & $63,96 \pm 39,51$ & 0,189 \\
\hline Vitamin B12 (pg/mL) & $460,96 \pm 231,47$ & $400,53 \pm 170,53$ & 0,602 \\
\hline Folate (mg/L) & $11,22 \pm 3,51$ & $13,56 \pm 5,69$ & 0,291 \\
\hline Vitamin D (ng/ml) & $17,50 \pm 8,22$ & $22,33 \pm 10,51$ & 0,233 \\
\hline Total IgA (mg/dL) & $150,45 \pm 66,94$ & $165,31 \pm 82,75$ & 0,564 \\
\hline
\end{tabular}

Table 4 Results of serological screening in DM and CD patients.

\begin{tabular}{|c|c|c|c|c|}
\hline & Clinical Variables & DM Group & CD Group & P-value \\
\hline TG IgA (mg/dL) & - & $8,08 \pm 33,86$ & $171,46 \pm 127,28$ & $0,000^{*}$ \\
\hline \multicolumn{5}{|l|}{$($ Mean \pm SD) } \\
\hline TG IgG (mg/dL) & - & $6,86 \pm 14,35$ & $46,20 \pm 37,63$ & $0,001^{*}$ \\
\hline \multicolumn{5}{|l|}{$($ Mean \pm SD $)$} \\
\hline EMA-IgA & Negative & $65(\% 95,6)$ & $1(\% 12,5)$ & $0,000^{*}$ \\
\hline n (\%) & Positive & $3(\% 4,4)$ & $7(\% 87,5)$ & \\
\hline EMA-IgG & Negative & $67(\% 98,5)$ & $3(\% 37,5)$ & $0,000^{*}$ \\
\hline n (\%) & Positive & $1(\% 1,5)$ & $5(\% 62,5)$ & \\
\hline HLADQ2 & Negative & $25(\% 41,0)$ & $2(\% 28,6)$ & 0,420 \\
\hline n (\%) & Positive & $36(\% 59,0)$ & $5(\% 71,4)$ & \\
\hline HLADQ8 & Negative & $28(\% 45,9)$ & $0(\% 0,0)$ & 0,019* \\
\hline n (\%) & Positive & $33(\% 54,1)$ & $7(\% 100,0)$ & \\
\hline
\end{tabular}

$*=p<0.05$ statistically significant.

Clinical characteristics of celiac patients are presented in Table 5. Selective IgA deficiency was described in $1 \mathrm{CD}-$ case. Anti-tTGA and EMA negativity was observed in a CDpatient due to the selective IgA deficiency, then HLA-DQ2/ HLA-DQ8 was found positive in this patient. In addition, HLA-DQ2/DQ8 positivity was observed in $62.5 \%(\mathrm{n}=5)$ of $\mathrm{CH}$ patients. HLA-DQ8 was found to be positive in all CD patients except a single patient with missing data. While a high rate of vitamin D deficiency was detected in the CD-cases (75\%), B12 deficiency was detected in only one CD-case. All patients with positive laboratory findings for $\mathrm{CD}$ underwent duodenal biopsy by gastroscopy and after histopathological evaluation; 2 were identified as Marsh Type 2, 2 were Marsh Type 3b and 2 were Marsh Type 3c.

Table 5 Clinical characteristics of CD patients.

\begin{tabular}{|l|l|l|l|l|l|l|l|l|l|l|l|l|l|}
\hline No & Gender & Age & $\begin{array}{l}\text { TG } \\
\text { IgA }\end{array}$ & $\begin{array}{l}\text { TG } \\
\text { IgG }\end{array}$ & $\begin{array}{l}\text { Total } \\
\text { IgA }\end{array}$ & $\begin{array}{l}\text { EMA } \\
\text { IgA }\end{array}$ & $\begin{array}{l}\text { EMA } \\
\text { IgG }\end{array}$ & HLADQ2 & HLADQ8 & Vit. D & Vit B12 & Folate & MARSH \\
\hline 1 & Female & 104 & + & + & N & + & + & + & + & 23,0 & 426 & 19,3 & Type 1 \\
\hline 2 & Male & 118 & + & + & $\mathrm{N}$ & + & + & - & + & 13,4 & 493 & 9,3 & Type 3C \\
\hline 3 & Male & 86 & + & - & $\mathrm{N}$ & + & - & + & + & 38,8 & 549 & 6,3 & Type 2 \\
\hline 4 & Female & 48 & + & + & $\mathrm{N}$ & + & + & + & + & 10,7 & 649 & 14,4 & Type 3C \\
\hline 5 & Female & 188 & + & + & $\mathrm{N}$ & + & + & - & + & 21,0 & 243 & 19,4 & Type 3B \\
\hline 6 & Male & 149 & - & + & $\mathrm{L}$ & - & + & + & + & 36,2 & 443 & 7,9 & Type 1 \\
\hline 7 & Male & 183 & + & + & $\mathrm{N}$ & + & + & + & + & 22,9 & 244 & 11,2 & Type 3B \\
\hline 8 & Female & 142 & - & + & $\mathrm{N}$ & + & - & - & + & 12,7 & 157 & 20,7 & Type 2 \\
\hline
\end{tabular}

${ }^{*} \mathrm{~N}$ : Normal, L: Low

\section{Discussion}

The risk of $\mathrm{CD}$ is significantly associated with female gender, young age and DM diagnosis especially at early ages [3]. In addition, patients mostly diagnosed with T1DM (75-80\%) before the onset of CD. Classic CD disease often diagnose aged between 2 to 3 years, while the mean age of T1DM comorbid CD is about 8 years at diagnosis [12]. Rami et al. reported a mean age of T1DM diagnosis as $6.5 \pm 4.1$ years and $\mathrm{CD}$ diagnosis as $10.0 \pm 5.4$ years in 98 children [13]. Similarly, Deja et al. reported a mean age of 7.39 years for T1DM and 8.43 years for CD diagnosis in 27 children. Researchers also documented no statistically significant differences according to the gender[14]. In accordance with these data, the mean age at diagnosis of DM was 95,67 $\pm 52,85$ months and CD was $109,20 \pm 56,10$ months Journal of Clinical Medicine of Kazakhstan: Volume 2, Number 56, Issue 2020 
in our study. Additionally, there was no significant differences found according to the gender.

In recent years it has been reported that the prevalence of CD in patients with T1DM has increased in worldwide and ranged from $4.4 \%$ to $11.1 \%$ in studies both with children and adults[12]. The CD prevalence in T1DM ranging from 4.4 to $6.4 \%$ in European countries and $10.5-11.1 \%$ in South America and India [15]. Ergür et al. documented a CD prevalence of $7,8 \%$ in 38 children with T1DM[16]. Supportively, the overall prevalence of CD in T1DM was found as $10.5 \%$ in present study.

The clinical presentation of the CD in TIDM is generally silent. Joshi et al. found positive TGA in 11 of 71 screened children, and 5 were $(7,04 \%)$ diagnosed with CD histopathologically. The researchers reported that the majority of CD-positive patients $(64 \%)$ were asymptomatic and frequently reported symptoms were puffiness, abdominal pain, and diarrhea. Moreover, researchers reported $45.5 \%$ vitamin D deficiency and $54.5 \%$ iron deficiency anemia in CD patients [17]. Tsouka et al. revealed 41-undiagnosed CD patients as a result of 771 serologically screened children with T1DM between 2005 and 2011 years. In same study 21 of 41 patients were asymptomatic and 10 of them had vitamin D deficiency [18]. Similarly in our study the $46.1 \%$ of the all patients and $37.5 \%$ of the CD patients were asymptomatic. The most common symptom reported in our patients was abdominal pain with a ratio of $32,9 \%$ followed by constipation $(25.0 \%)$, and diarrhea $(11,8 \%)$ respectively. There were no statistically significant differences found between the $\mathrm{CD}$ and T1DM groups according to the age, BMI and laboratory findings. Vitamin D deficiency was detected in $88,2 \%$ of all patients, folic acid deficiency in $1.3 \%$ and vitamin B12 deficiency in $9.2 \%$. Iron-deficiency anemia detected in only 1 patient and a high rate of vitamin D deficiency was detected in the CD-cases (75\%).

Although histopathological evaluation for $\mathrm{CD}$ diagnosis in T1DM patients is the gold standard, serological screening via TGA and EMA is highly valuable particularly in detecting asymptomatic patients. As a result of serologic screening in 268 patients with T1DM, Ozdemir et al. reported 8 EMA positive, 13 TGA positive patients and normal IgA levels in all patients. Researchers confirmed CD diagnosis in $5(1.9 \%)$ patients. They revealed positive EMA and TGA in all of these 5 patients, additionally reported $100 \%, 100 \%$ sensitivity, and 95\%, 86\% specificity for these two tests respectively [19]. Yildirmaz et al. reported $16(7.3 \%)$ TGA positive cases in 218 T1DM patients and $\mathrm{CD}$ diagnosis confirmed in $11(5 \%)$ of these TGA positive cases. As a result of histopathological evaluation; 3 were identified as Marsh Type 2, 1 were Marsh Type 3a, 4 were Marsh Type $3 b$ and 3 were Marsh Type $3 c$ in same study [20]. Bolad et al. documented $10,1 \%$ TG and 7,2\% EMA positivity in a study comparing $69 \mathrm{~T} 1 \mathrm{DM}$ patients with healthy controls. Researchers also noted significantly higher TGA-G titres than healthy controls [21]. Singh et al. detected positive CD serology in 43 (34.1\%) of $126 \mathrm{~T} 1 \mathrm{DM}$ patients. The CD diagnosis confirmed in 17 patients (13.5\%) by histopathological examination [22]. Supportively in present study, anti-tTGA was positive in $14,5 \%$, and anti-EMA was positive in $13,2 \%$ of all patients. Of the CD patients, 6 were anti-tTGA and 7 were EMA positive. According to the histopathological evaluation of $\mathrm{CD}$ patients; 2 were identified as Marsh Type 2, 2 were Marsh Type $3 b$ and 2 were Marsh Type 3c.

HLA plays a prominent role in the genetic predisposition to celiac disease, supportively there is a strong association between HLA-DQ2/DQ8 and CD. This relationship is so strong that $\mathrm{CD}$ is rarely found in individuals with HLA-DQ2 and HLADQ8 negative. HLA-DQ2 is responsible for the prevalence of $\mathrm{CD}$ in T1DM[23]. Ghawil et al. detected 75\% HLADQ2, 21\% HLA-DQ2 / HLA-DQ8 and 4\% HLA-DQ8 in 24 CD patients with T1DM ( $n=218)$ [24]. Dezsofi et al. defined DQ2 / DQ8 heterozygosity as a risk factor for both $\mathrm{CD}$ and T1DM in a study consisted of 80 children with T1DM, 100 children with $\mathrm{CD}$, and 47 children with CD+T1DM. Researchers stated that homozygous HLA-DQ8 genotype in T1DM patients and HLA-DQ2 / DQ8 heterozygosity in CD+T1DM patients were significantly higher than CD- patients and healthy controls [25]. In addition, HLA-DQ8 was the most frequently detected genotype in a study conducted by Ergür et al. among CD patients [16]. In accordance with these data, HLADQ2 was positive in $60.3 \%$ and HLA-DQ8 was positive in $58.8 \%$ of all patients in our study. HLA-DQ8 ratio was significantly higher in patients diagnosed with CD than the T1DM patients. Moreover, HLADQ2/DQ8 positivity was observed in $62.5 \%(n=5)$ of $C D$ patients. Additionally, HLA-DQ8 was found to be positive in all $\mathrm{CD}$ patients except a single patient with missing data. Furthermore, HLA-DQ2/HLA-DQ8 was found positive in a patient with selective IgA deficiency.

In conclusion, our findings have demonstrated the increasing prevalence of CD in children with T1DM. Particularly the higher risk of asymptomatic CD in T1DM patients, revealed the diagnostic value of serological screening. Furthermore, increased HLA-DQ2 and HLA-DQ8 positivity, which are more prominent in case of selective IgA deficiency, clearly demonstrates the requirement of routine total $\operatorname{IgA}$ and HLA analysis in serological screening.

Disclosures: There is no conflict of interest for all authors.

\section{References}

1. Volta U, Tovoli F, Caio G. Clinical and immunological features of celiac disease in patients with type 1 diabetes mellitus. Expert review of gastroenterology \& hepatology. 2011; 5(4):479-87. https://doi.org/10.1586/egh.11.38

2. Triolo TM, Armstrong TK, McFann K, Yu L, Rewers MJ, Klingensmith GJ, Eisenbarth GS, Barker JM. Additional autoimmune disease found in 33\% of patients at type 1 diabetes onset. Diabetes care. 2011; 34(5):1211-3. https://doi.org/10.2337/dc10-1756

3. Pham-Short A, Donaghue KC, Ambler G, Phelan H, Twigg S, Craig ME. Screening for celiac disease in type 1 diabetes: a systematic review. Pediatrics. 2015; 136(1):e170-6. https://doi.org/10.1542/peds.2014-2883

4. Mahmud FH, Murray JA, Kudva YC, Zinsmeister AR, Dierkhising RA, Lahr BD, Dyck PJ, Kyle RA, El-Youssef M, Burgart LJ, Van Dyke CT. Celiac disease in type 1 diabetes mellitus in a North American community: prevalence, serologic screening, and clinical features. InMayo Clinic Proceedings. 2005; 80(11):1429-1434). Elsevier. https://doi.org/10.4065/80.11.1429

5. Elfström P, Sundström J, Ludvigsson JF. Systematic review with meta-analysis: associations between coeliac disease and type 1 diabetes. Alimentary pharmacology \& therapeutics. 2014; 40(10):1123-32. https://doi.org/10.1111/apt.12973

6. Ludvigsson JF, Ludvigsson J, Ekbom A, Montgomery SM. Celiac disease and risk of subsequent type 1 diabetes: a general population cohort study of children and adolescents. Diabetes Care. 2006; 29:2483-8. https://doi.org/10.2337/dc06-0794 
7. Valerio G, Maiuri L, Troncone R et al. Severe clinical onset of diabetes and increate prevalence of other autoimmune diseases in children with celiac disease diagnosed before diabetes mellitus. Diabetologica. 2002; 45 (12):1719-1722. https://doi.org/10.1007/s00125-0020923-5

8. Leeds JS, Hopper AD, Hadjivassiliou M, Tesfaye S, Sanders DS. High prevalence of microvascular complications in adults with type 1 diabetes and newly diagnosed celiac disease. Diabetes care. 2011; 34(10):2158-63. https://doi.org/10.2337/dc11-0149

9. Holmes GK. Coeliac disease and Type 1 diabetes mellitus-the case for screening. Diabetic Medicine. 2001; 18(3):169-77. https://doi. org/10.1046/j.1464-5491.2001.00498.x

10. Pham-Short A, Donaghue KC, Ambler G, Phelan H, Twigg S, Craig ME. Screening for celiac disease in type 1 diabetes: a systematic review. Pediatrics. 2015; 136(1):e170-6. https://doi.org/10.1542/peds.2014-2883

11. Oberhuber G, Granditsch G, Vogelsang H. The histopathology of coeliac disease: time for a standardized report scheme for pathologists. European journal of gastroenterology \& hepatology. 1999; 11(10):1185-94. https://doi.org/10.1097/00042737-199910000-00019

12. Camarca ME, Mozzillo E, Nugnes R, Zito E, Falco M, Fattorusso V, Mobilia S, Buono P, Valerio G, Troncone R, Franzese A. Celiac disease in type 1 diabetes mellitus. Italian journal of pediatrics. 2012; 38(1):10. https://doi.org/10.1186/1824-7288-38-10

13. Rami B, Sumnik Z, Schober E, Waldhör T, Battelino T, Bratanic N, Kürti K, Lebl J, Limbert C, Madacsy L, Odink RJ. Screening detected celiac disease in children with type 1 diabetes mellitus: effect on the clinical course (a case control study). Journal of pediatric gastroenterology and nutrition. 2005; 41(3):317-21. https://doi.org/10.1097/01.mpg.0000174846.67797.87

14. Deja G, Myrda A, Jarosz-Chobot P, Siekiera U. The assessment of autoimmunological status and prevalence of different forms of celiac disease among children with type 1 diabetes mellitus and celiac disease. Mediators of inflammation. 2008. https:/doi. org/10.1155/2008/285989

15. Akirov A, Pinhas-Hamiel O. Co-occurrence of type 1 diabetes mellitus and celiac disease. World journal of diabetes. $2015 ; 6(5): 707$. https://doi.org/10.4239/wjd.v6.i5.707

16. Ergür AT, Öçal G, Berberoğlu M, Adıyaman P, Şıklar Z, Aycan Z, Evliyaoğlu O, Kansu A, Girgin N, Ensari A. Celiac Disease and Autoimmune Thyroid Disease in Children with Type 1 Diabetes Mellitus: Clinical and HLA- Genotyping Results. Journal of clinical research in pediatric endocrinology. 2010; 2(4):151. https://doi.org/10.4274/jcrpe.v2i4.151

17. Joshi R, Madvariya M. Prevalence and clinical profile of celiac disease in children with type 1 diabetes mellitus. Indian journal of endocrinology and metabolism. 2015; 19(6):797. https://doi.org/10.4103/2230-8210.167555

18. Tsouka A, Mahmud FH, Marcon MA. Celiac disease alone and associated with type 1 diabetes mellitus. Journal of pediatric gastroenterology and nutrition. 2015; 61(3):297-302. https://doi.org/10.1097/MPG.0000000000000789

19. Ozdemir H, Kutlu T, Ozdemir M, Isguven P, Erkan T, Cokugras FC, Dervisoglu S. Prevalence of celiac disease in children with type 1 diabetes mellitus and the accuracy of serological tests. Medicine. 2018; 7(4):882-5. https://doi.org/10.5455/medscience.2018.07.8901

20. Yildirmaz S, Altay D, Esen I, Dogan Y. Prevalence of Celiac Disease in Children With Type 1 Diabetes Mellitus in Southeast Region of Turkey. International Journal of Clinical Pediatrics. 2016; 5(2):32-5. https://doi.org/10.14740/ijcp239w

21. Bolad A, Farouk A, Lutfi MF, Nemeiri M. Association between diabetes mellitus type 1 and celiac disease: case-control study among Sudanese patients 2009-2011. Sudan Journal of Medical Sciences. 2012; 7(2):105-10.

22. Singh P, Seth A, Kumar P, Sajjan S. Coexistence of celiac disease \& type 1 diabetes mellitus in children. The Indian journal of medical research. 2017; 145(1):28. https://doi.org/10.4103/ijmr.IJMR_199_15

23. Akirov A, Pinhas-Hamiel O. Co-occurrence of type 1 diabetes mellitus and celiac disease. World journal of diabetes. $2015 ; 6(5): 707$. https://doi.org/10.4239/wjd.v6.i5.707

24. Ghawil M, Miotti V, Tonutti E, Tenore A, Hadeed I, Sindici C, Visentini D, Morgham A, Abusrewil S. HLA-DQ types of celiac disease in Libyan children with type 1 diabetes mellitus. European journal of gastroenterology \& hepatology. 2012; 24(1):59-63. https://doi. org/10.1097/MEG.0b0 13e32834d09d4

25. Dezsofi A, Szebeni B, Hermann CS, Kapitany A, Veres G, Sipka S, Körner A, Madácsy L, Korponay-Szabó I, Rajczy K, Arató A. Frequencies of genetic polymorphisms of TLR4 and CD14 and of HLA-DQ genotypes in children with celiac disease, type 1 diabetes mellitus, or both. Journal of pediatric gastroenterology and nutrition. 2008; 47(3):283-7. https://doi.org/10.1097/ MPG.0b013e31816de885

How to cite this article: Hasret Ayyıldız Civan, Esra Papatya Çakır. Screening of celiac disease in children and adolescents with type 1 diabetes mellitus. J Clin Med Kaz. 2020; 2(56):21-26 